\title{
Iron Isotope Fractionations Reveal a Finite Bioavailable Fe Pool for Structural Fe(III) Reduction in Nontronite
}

Bingjie Shi, ${ }^{\dagger,}$ Kai Liu, ${ }^{\dagger, \ddagger}$ Lingling Wu, ${ }^{, \dagger, \ddagger}$ Weiqiang Li, ${ }^{\S, \|}$ Christina M. Smeaton, ${ }^{\dagger, \ddagger}$ Brian L. Beard, ${ }^{\S, \|}$ Clark M. Johnson, ${ }^{\S, \|}$ Eric E. Roden, ${ }^{\S, \|}$ and Philippe Van Cappellen ${ }^{\dagger,+}$

${ }^{\dagger}$ Department of Earth and Environmental Sciences, University of Waterloo, Waterloo, Ontario N2L 3G1, Canada

${ }^{\ddagger}$ Water Institute, University of Waterloo, Waterloo, Ontario N2L 3G1, Canada

${ }^{\S}$ Department of Geoscience, University of Wisconsin-Madison, Madison, Wisconsin 53706, United States

"NASA Astrobiology Institute, University of Wisconsin-Madison, Madison, Wisconsin 53706, United States

\section{Supporting Information}

ABSTRACT: We report on stable $\mathrm{Fe}$ isotope fractionation during microbial and chemical reduction of structural $\mathrm{Fe}$ (III) in nontronite NAu-1. ${ }^{56} \mathrm{Fe} /{ }^{54} \mathrm{Fe}$ fractionation factors between aqueous $\mathrm{Fe}$ (II) and structural $\mathrm{Fe}$ (III) ranged from -1.2 to $+0.8 \%$. Microbial (Shewanella oneidensis and Geobacter sulfurreducens) and chemical (dithionite) reduction experiments revealed a two-stage process. Stage 1 was characterized by rapid reduction of a finite $\mathrm{Fe}$ (III) pool along the edges of the clay particles, accompanied by a limited release to solution of $\mathrm{Fe}(\mathrm{II})$, which partially adsorbed onto basal planes. Stable Fe isotope compositions revealed that electron transfer and atom exchange (ETAE) occurred between edge-bound $\mathrm{Fe}$ (II) and octahedral (structural) Fe(III) within the clay lattice, as well as between aqueous $\mathrm{Fe}$ (II) and structural $\mathrm{Fe}$ (III) via a transient sorbed phase. The isotopic fractionation factors decreased with increasing extent of reduction as a result of the depletion of the finite bioavailable Fe(III) pool. During stage 2, microbial reduction was inhibited while chemical reduction continued. However, further ETAE between aqueous Fe(II) and structural $\mathrm{Fe}$ (III) was not observed. Our results imply that the pool of bioavailable Fe(III) is restricted to structural Fe sites located near the edges of the clay particles. Blockage of ETAE distinguishes Fe(III) reduction of layered clay minerals from that of Fe oxyhydroxides, where accumulation of structural $\mathrm{Fe}(\mathrm{II})$ is much more limited.

\section{INTRODUCTION}

Transformations of clay minerals in near-surface environments influence soil fertility, contaminant mobility, and hydrocarbon maturation. ${ }^{1-4}$ Iron ( $\mathrm{Fe}$ ) is ubiquitous in clay minerals. ${ }^{5,6}$ The oxidation state of structural Fe greatly influences the physical and chemical properties of clay minerals, including specific surface area, cation exchange capacity, structure and stability, as well as hydration and swelling. ${ }^{6-9}$ These processes in turn determine the fate of contaminants such as metal cations, ${ }^{10}$ radionuclides, ${ }^{11}$ and organic contaminants. ${ }^{12}$ Structural Fe(III) in clay minerals also represents a potentially renewable source of terminal electron acceptor for dissimilatory $\mathrm{Fe}$ (III)-reducing bacteria in soils and sediments, as Fe(III) in clay minerals is not subjected to reductive dissolution to the same extent as in Fe(III) oxyhydroxides. ${ }^{13-15}$

Although the importance of clay transformation by microbes has been recognized over the last two decades, the electron transfer and atom exchange pathways during reduction of structural $\mathrm{Fe}(\mathrm{III})$ in clays remain unclear. ${ }^{16,17}$ Microbial reduction of $\mathrm{Fe}(\mathrm{III})$ in clays has been proposed to start from the edges and progress through the octahedral sheet as a moving front, ${ }^{18}$ in contrast to a pseudorandom chemical reduction starting from the basal plane surfaces. ${ }^{19}$ Two mechanisms for microbial reduction of $\mathrm{Fe}$ (III) in clays have further been suggested: solid-state and dissolution-precipitation, where the former refers to reduction within the clay structure without significant release of $\mathrm{Fe}$ (II) to the aqueous phase, ${ }^{20,21}$ and the latter to dissolution of the clay structure and precipitation of secondary minerals. ${ }^{15,22,23}$ Operation of either mechanism may depend on the clay mineral, growth medium composition, and the density and type of microorganisms. ${ }^{17}$

Stable $\mathrm{Fe}$ isotopes are a powerful tracer of biogeochemical processes involving redox transformations of $\mathrm{Fe}$ minerals. ${ }^{24}$ Iron isotope compositions in natural environments span a range of up to $6 \% 0$ in $\delta^{56} \mathrm{Fe}$ values (defined as the ${ }^{56} \mathrm{Fe} /{ }^{54} \mathrm{Fe}$ ratio of a sample relative to a reference material, such as igneous rocks), ${ }^{25,26}$ with the largest variations observed in Precambrian marine sedimentary rocks. ${ }^{24}$ Both biological and abiological processes can fractionate $\mathrm{Fe}$ isotopes, with the largest fractionations associated with redox changes. ${ }^{27,28}$ Coupled electron and atom exchange has been shown to be

Received: April 25, 2016

Revised: June 10, 2016

Accepted: June 12, 2016

Published: June 13, 2016 
Table 1. Experimental Design

\begin{tabular}{|c|c|c|c|c|c|c|}
\hline experiments & setup & $\begin{array}{l}\text { number of } \\
\text { reactors }\end{array}$ & processes & $\begin{array}{l}\text { presence of } \\
\mathrm{Fe}(\mathrm{II})\end{array}$ & $\begin{array}{l}\text { electron } \\
\text { transfer }\end{array}$ & $\begin{array}{l}\text { atom } \\
\text { exchange }\end{array}$ \\
\hline abiotic control & NAu-1 + medium & 1 & nonreductive dissolution & no & no & yes \\
\hline $\begin{array}{l}\text { biological } \\
\text { reduction }\end{array}$ & $\begin{array}{l}\text { NAu- } 1+\text { medium }+ \text { cells (Shewallena) } \\
\text { Geobacter) }\end{array}$ & 2 duplicates & $\begin{array}{l}\text { reduction, dissolution (reductive and } \\
\text { nonreductive) }\end{array}$ & yes & yes & yes \\
\hline $\begin{array}{l}\text { chemical } \\
\text { reduction }\end{array}$ & NAu-1 + dithionite & 6 individuals & $\begin{array}{l}\text { reduction, dissolution (reductive and } \\
\text { nonreductive) }\end{array}$ & yes & yes & yes \\
\hline abiotic exchange & NAu-1 + Fe(II) (4:1 molar Fe ratio) & 2 duplicates & $\begin{array}{l}\text { exchange (equivalent to a fixed extent of } \\
\text { reduction) }\end{array}$ & yes & yes & yes \\
\hline
\end{tabular}

the mechanism responsible for $\mathrm{Fe}$ isotope fractionation during microbial $\mathrm{Fe}(\mathrm{III})$ oxide reduction, ${ }^{29-31}$ as well as during abiological interaction between aqueous $\mathrm{Fe}$ (II) and $\mathrm{Fe}$ (III) oxides. ${ }^{32-34}$ Here, we use Fe isotope fractionations as a tracer to investigate atom exchange and changes in bonding that are produced by both microbial and chemical reduction of Fe-rich smectite NAu-1. A similar approach has proven valuable in understanding electron transfer and atom exchange (ETAE) pathways during reduction of structural $\mathrm{Fe}(\mathrm{III})$ in oxides/ hydroxides. Notwithstanding extensive research on microbial and chemical reduction of structural $\mathrm{Fe}$ (III) in clay minerals, ${ }^{15-23}$ no information currently exists on the partitioning of $\mathrm{Fe}$ isotopes during reduction of structural $\mathrm{Fe}(\mathrm{III})$ in clays. This study aims to provide new insights into ETAE pathways during reduction of structural $\mathrm{Fe}$ in clay minerals.

\section{MATERIALS AND METHODS}

Clay Mineral Preparation. Nontronite NAu-1 [(Ca, Na, K) $\left.{ }_{1.05}\left[\mathrm{Si}_{6.98} \mathrm{Al}_{1.02}\right]\left[\mathrm{Al}_{0.29} \mathrm{Fe}_{3.68} \mathrm{Mg}_{0.04}\right] \mathrm{O}_{20}(\mathrm{OH})_{4}\right]$ was obtained from the Clay Minerals Society ${ }^{35}$ and further treated by a size-fractionation $(<0.5 \mu \mathrm{m}), \mathrm{Na}^{+}$-homoionization and purification process. ${ }^{36,37}$ The purified nontronite was freeze-dried, pulverized and then sieved (100 mesh/150 $\mu \mathrm{m})$. X-ray diffraction (XRD) and scanning electron microscopy (SEM) coupled to energy dispersive spectroscopy (EDS) analysis showed no evidence for the presence of impurities, such as goethite, quartz, or kaolin, in the purified NAu-1 (Supporting Information (SI) Figures S1 and S2).

Microbial and Chemical Reduction Experiments. An overview of the experimental design is given in Table 1, additional details can be found in SI Table S1. Shewanella oneidensis MR-1 ${ }^{38}$ was grown aerobically in LB media, prior to inoculation of the clay-bearing suspensions. Cells were harvested and washed twice with sterile HEPES buffer before adding $2 \times 10^{8}$ cells $/ \mathrm{mL}$ to $120 \mathrm{~mL}$ of HEPES buffer $(100 \mathrm{mM}$, $\mathrm{pH}$ 6.8) containing $5 \mathrm{mg} / \mathrm{mL}$ NAu-1 [Fe(III) electron acceptor], $40 \mathrm{mM}$ Na-lactate (electron donor), $100 \mu \mathrm{M}$ $\mathrm{KH}_{2} \mathrm{PO}_{4}$, and $5 \mathrm{mM}\left(\mathrm{NH}_{4}\right)_{2} \mathrm{SO}_{4}$. Geobacter sulfurreducens strain $\mathrm{PCA}^{39}$ was incubated with fumarate (electron acceptor) and acetate (carbon and energy source) prior to inoculation. Cells were harvested and washed once with sterile, anaerobic PIPES buffer before adding $5 \times 10^{8}$ cells $/ \mathrm{mL}$ to $120 \mathrm{~mL}$ anaerobic, $\mathrm{H}_{2}$-saturated PIPES buffer $(10 \mathrm{mM}, \mathrm{pH} 6.8)$ containing $5 \mathrm{mg} / \mathrm{mL} \mathrm{NAu}-1$. Acetate (final $20 \mathrm{mM}$ ) and the electron shuttle anthraquinone-2,6-disulfonate (AQDS, final 0.1 $\mathrm{mM}$ ) were successively added to the Geobacter reactors 137 days and 155 days after initiating the experiments, respectively.

In order to maintain anaerobic conditions, the glass reactors were crimp sealed using gas impermeable butyl rubber stoppers, and shaken at $100 \mathrm{rpm}$. Duplicate biotic and abiotic (cell-free) control reactors were prepared. The $\mathrm{pH}$ values in the biotic reactors remained stable at 6.8 even after more than 400 days of incubation. Parallel abiotic reduction reactors were prepared by adding 15 to $200 \mathrm{mg}$ sodium dithionite to $10 \mathrm{~mL} 100 \mathrm{mM}$ HEPES buffer ( $\mathrm{pH} 6.8)$ with NAu-1 $(5 \mathrm{mg} / \mathrm{mL})$ to achieve an analogous or greater extent of reduction as observed in the biotic reactors. The abiotic reactors were kept at room temperature, or at $70{ }^{\circ} \mathrm{C}$ to achieve a higher extent of reduction (SI Table S1). Limited reaction time was employed to avoid a much higher extent of reduction (i.e., 20 days for nearly $100 \%$ reduction as in a previous study ${ }^{40}$ ).

Exchange Experiments of $\mathrm{Fe}$ (II) with NAu-1. A ${ }^{57} \mathrm{Fe}-$ enriched $\mathrm{Fe}(\mathrm{II})$ stock solution $\left(\delta^{56 / 54} \mathrm{Fe}=-0.49 \%\right.$ and $\left.\delta^{57 / 56} \mathrm{Fe}=+104.83 \% 0\right)$ was prepared by mixing a ${ }^{57} \mathrm{Fe}$-enriched spike with a natural abundance $\mathrm{Fe}(\mathrm{II})$ solution at a molar ratio of ca. 1:500. Batch reactors contained $15 \mathrm{~mL}$ of $25 \mathrm{mM}$ MES buffer adjusted to $\mathrm{pH} 6.0,50 \mathrm{mM} \mathrm{NaCl}$ to provide a constant ionic strength, and $2 \mathrm{mM}$ of ${ }^{57} \mathrm{Fe}$-enriched aqueous $\mathrm{Fe}(\mathrm{II})$. The reaction was started by adding $30.0 \mathrm{mg}$ of purified NAu-1 powder to the reactors.

Fe Extractions and Chemical Analysis. At selected time points during the reduction experiments, $10 \mathrm{~mL}$ of the clay suspensions were collected from each reactor and centrifuged $(6500 \mathrm{rpm}, 15 \mathrm{~min})$. The supernatant was filtered $(0.2 \mu \mathrm{m})$ to isolate the aqueous fraction. The remaining solid was extracted for $4 \mathrm{~h}$ with $1 \mathrm{M} \mathrm{CaCl}_{2}(\mathrm{pH} 7)$ to remove the $\mathrm{Fe}(\mathrm{II})$ sorbed on the clay mineral basal planes. ${ }^{36}$ This extraction relies on the displacement of basal plane sorbed $\mathrm{Fe}^{2+}$, including interlayer $\mathrm{Fe}^{2+}$, by excess $\mathrm{Ca}^{2+} .{ }^{41}$ The mixture was centrifuged, filtered and acidified for preservation. Then the remaining solid was mixed with $5 \mathrm{~mL} 1 \mathrm{M} \mathrm{NaH}_{2} \mathrm{PO}_{4}$ ( $\mathrm{pH} \mathrm{5)}$ for $18 \mathrm{~h}$ to isolate the $\mathrm{Fe}(\mathrm{II})$ sorbed to the clay mineral edge OH-groups. ${ }^{36}$ This extraction is based on the high affinity of $\mathrm{Fe}-\mathrm{OH}$ groups for phosphate ions. $^{42}$ In addition to edge-bound $\mathrm{Fe}(\mathrm{II})$, this extraction may also partially recover structural $\mathrm{Fe}(\mathrm{II}) .^{33}$ The remaining solid was mixed with $5 \mathrm{~mL} 0.5 \mathrm{M} \mathrm{HCl}$ for $24 \mathrm{~h}$ to extract the residual structural $\mathrm{Fe}(\mathrm{II}) .{ }^{5}$ Note that $0.5 \mathrm{M} \mathrm{HCl}$ may also partially remove structural $\mathrm{Fe}$ (III). The mixture solution was centrifuged and filtered. For chemical reactors, the residual solid after the $0.5 \mathrm{M} \mathrm{HCl}$ extraction was further treated with $48 \% \mathrm{HF}$ to quantify any remaining structural $\mathrm{Fe}(\mathrm{II}) .^{43}$

Iron(II) concentrations were determined spectrophotometrically using Ferrozine ${ }^{44}$ for the reduction experiments and 1,10phenanthroline $^{45}$ for the exchange experiments. Total $\mathrm{Fe}$ [Fe(tot)] was measured after addition of $10 \%$ hydroxylamine hydrochloride to reduce $\mathrm{Fe}(\mathrm{III})$. The $\mathrm{Fe}(\mathrm{III})$ concentration was then calculated as the difference of $\mathrm{Fe}$ (tot) and $\mathrm{Fe}$ (II). In the HF treatment, 1,10-phenanthroline monohydrate was used to form strong tris complexes with $\mathrm{Fe}(\mathrm{II})$ in the $\mathrm{HF}-\mathrm{H}_{2} \mathrm{SO}_{4}$ matrix. ${ }^{43} \mathrm{Next}, \mathrm{H}_{3} \mathrm{BO}_{4}$ and $\mathrm{Na}_{2}$-citrate were added and the absorbance was measured at $510 \mathrm{~nm}$. This method has been shown to quantitatively determine $\mathrm{Fe}$ (II) in silicate minerals. ${ }^{43}$ 
Aqueous silica concentrations were analyzed using a standard colorimetric method. ${ }^{46}$

Fe Isotope Analysis. Test solutions, used to check the accuracy of $\mathrm{Fe}$ isotope analyses, were prepared by adding $50 \mu \mathrm{g}$ of HPS (high purity standard) Fe to $10 \mathrm{~mL} 100 \mathrm{mM}$ HEPES buffer, 0.5 to $5 \mathrm{~mL} 1 \mathrm{M} \mathrm{CaCl}_{2}, 0.5$ to $5 \mathrm{~mL} 1 \mathrm{M} \mathrm{NaH}_{2} \mathrm{PO}_{4}$, or 3 to $10 \mathrm{~mL} 2.5$ to $15 \mathrm{mg} / \mathrm{mL}$ dithionite in order to identify potential $\mathrm{Fe}$ isotope fractionation artifacts produced during the chemical extractions or by the use of dithionite as chemical reductant. Wet chemistry was performed on the solutions to separate Fe from other cations by passing them through an anion-exchange resin. ${ }^{47}$ Iron isotope compositions of the aqueous fractions, extracts and test solutions were measured by a multicollector, inductively coupled plasma mass spectrometer (MC-ICP-MS) at University of Wisconsin, Madison, following established protocols. ${ }^{47}$ All $\mathrm{Fe}$ isotope data were reported as $\delta^{56} \mathrm{Fe}$ in units of per mil (\%o) relative to average terrestrial igneous rocks $\left(\delta^{56} \mathrm{Fe}=0.00 \pm 0.05 \%{ }^{47}\right)$. Stable $\mathrm{Fe}$ isotope fractionation between two phases $\mathrm{A}$ and $\mathrm{B}$ is defined as $\Delta^{56} \mathrm{Fe}_{\mathrm{A}-\mathrm{B}}=\delta^{56} \mathrm{Fe}_{\mathrm{A}}-\delta^{56} \mathrm{Fe}_{\mathrm{B}}$, following standard practice. Measured external precision for $\delta^{56} \mathrm{Fe}$ was $\pm 0.05 \%$ o $(2 \sigma, n=37)$. The average $\delta^{56} \mathrm{Fe}$ value of the test solutions was $0.50 \pm 0.08 \%$ o $(2 \sigma ; n=24)$, which is identical to the isotope composition measured for the pure HPS Fe solutions $\left(\delta^{56} \mathrm{Fe}=\right.$ $0.49 \pm 0.06 \% \circ ; 2 \sigma ; n=27)$. The measured Fe isotope composition of the IRMM-019 Fe isotope standard was -0.08 $\pm 0.05 \%$ o $(2 \sigma ; n=48)$, which lies within error of the long-term value in the UW-Madison lab of $-0.09 \%$ relative to the average of igneous rocks.

\section{RESULTS}

Microbial and Chemical Reduction of NAu-1. Smectite has a 2:1 layer structure in which an octahedral sheet is bound by two tetrahedral sheets through sharing the apical oxygens. ${ }^{48}$ Structural Fe(III) in NAu-1 $\left(\sim 22\right.$ wt $\left.\%^{35}\right)$ is located in the octahedral sheet with edge sites exposed to solution. Reduction of structural $\mathrm{Fe}$ (III) in the biological and chemical experiments was monitored by measuring $\mathrm{Fe}$ (II) in the aqueous phase and in the solutions produced by the three sequential wet-chemical extraction steps: i. $1 \mathrm{M} \mathrm{CaCl}_{2}$, which quantitatively removes $\mathrm{Fe}$ (II) sorbed onto basal planes; ii. $1 \mathrm{M} \mathrm{NaH}_{2} \mathrm{PO}_{4}$, which releases $\mathrm{Fe}(\mathrm{II})$ bound to $\mathrm{OH}$-group at edge sites and partial structural $\mathrm{Fe}(\mathrm{II})$; and iii. $0.5 \mathrm{M} \mathrm{HCl}$, which removes structural $\mathrm{Fe}(\mathrm{II})$ and a portion of structural $\mathrm{Fe}$ (III). The $\mathrm{Fe}$ (II) and $\mathrm{Fe}$ (tot) data showed that Fe released to aqueous solution and $\mathrm{Fe}$ in the first two extractions were entirely comprised of $\mathrm{Fe}(\mathrm{II})$, while the $0.5 \mathrm{M} \mathrm{HCl}$ extracts contained a mixture of $\mathrm{Fe}(\mathrm{II})$ and $\mathrm{Fe}(\mathrm{III})$ (SI Table S2). In other words, structural Fe(III) is the only $\mathrm{Fe}$ (III) phase throughout our experiments. The selective release of basal plane sorbed $\mathrm{Fe}(\mathrm{II})$ and edge $\mathrm{OH}$-group bound $\mathrm{Fe}(\mathrm{II})$ during the first two extractions has previously been confirmed by Mössbauer analysis of Fe(II)-reacted NAu-1 and the reference Fe-free montmorillonite SYn-1. ${ }^{36}$ It is not possible to resolve whether edge-bound $\mathrm{Fe}(\mathrm{II})$ derives from in situ reduction or readsorbed $\mathrm{Fe}$ (II).

In the biological reduction experiments with Shewanella and Geobacter, Fe(II) concentrations increased with time (Figure 1, SI Table S2). Edge plus structural $\mathrm{Fe}(\mathrm{II})$ accounted for the largest fraction of biogenic $\mathrm{Fe}$ (II) (55-71\%; SI Table S3, Figure S3), structural $\mathrm{Fe}(\mathrm{II})$ in the interior of the NAu-1 accounted for 13 to $21 \%$ of total produced $\mathrm{Fe}(\mathrm{II})$, and aqueous $\mathrm{Fe}(\mathrm{II})$ accounted for $4-12 \%$ total produced Fe(II). Only 2-7\% of the $\mathrm{Fe}(\mathrm{II})$ released in the experiments with Shewanella

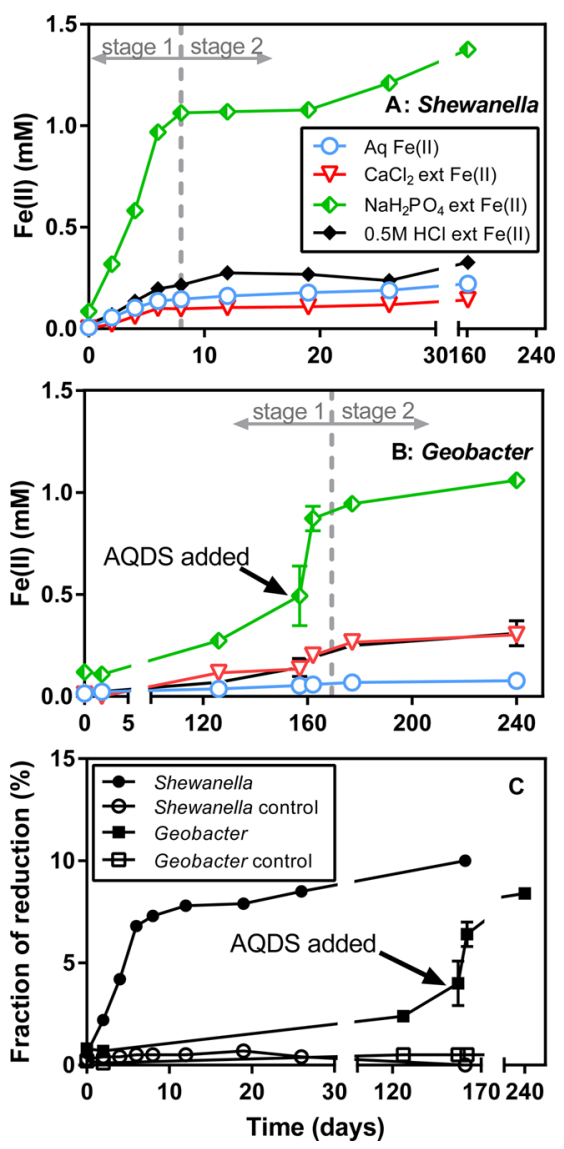

Figure 1. Time-dependent buildup of different Fe(II) pools during biological reduction of NAu-1 by Shewallena (panel A) and Geobacter (panel B). The pools include dissolved $\mathrm{Fe}(\mathrm{II}), 1 \mathrm{M} \mathrm{CaCl}_{2}$ extractable $\mathrm{Fe}(\mathrm{II})$ (basal planes), $1 \mathrm{M} \mathrm{NaH}_{2} \mathrm{PO}_{4}$ extractable $\mathrm{Fe}(\mathrm{II})$ (edge plus structural sites), and $0.5 \mathrm{M} \mathrm{HCl}$ extractable $\mathrm{Fe}(\mathrm{II})$ (interior sites). The electron shuttle AQDS was added after 155 days to the Geobacter reactors to facilitate reduction. The vertical gray lines indicate the transition from stage 1 to stage 2 . The fraction of reduction was calculated as the total $\mathrm{Fe}(\mathrm{II})$ relative to the initial total $\mathrm{Fe}$ of NAu-1 (panel C). Error bars indicate one standard deviation from duplicate reactors. No reduction was observed in controls where no cells were present.

sorbed onto basal planes. During NAu-1 reduction by Geobacter in the presence of AQDS, a larger fraction (15-17\%) of basal plane sorbed $\mathrm{Fe}(\mathrm{II})$ was observed. However, together aqueous and basal-sorbed $\mathrm{Fe}$ (II) accounted for a fairly constant fraction of the total Fe(II) produced by Shewanella and Geobacter (18 \pm $2 \%$, SI Table S3, Figure S3).

In the chemical reduction experiments (i.e., without bacteria), edge plus structural $\mathrm{Fe}$ (II) accounted for 54-64\% of total Fe(II) (SI Table S3, Figure S3), similar to that of biological experiments. Interior structural $\mathrm{Fe}(\mathrm{II})$ accounted for $22-41 \%$ of total $\mathrm{Fe}$ (II) and showed an increasing trend with increasing extent of reduction. Compared to the biological reduction experiments, the larger fraction of interior structural $\mathrm{Fe}(\mathrm{II})$, for a comparable extent of reduction (SI Table S3, Figure S3), suggests that dithionite was able to reduce more of the interior pool of octahedral $\mathrm{Fe}(\mathrm{III})$, probably due to the small molecular size of dithionite $(\mathrm{S}-\mathrm{O}$ and $\mathrm{S}-\mathrm{S}$ bond length of 1.5 and $2.3 \AA$, respectively ${ }^{49}$ ), enabling it to diffuse into the clay interior through the basal planes (hexagonal cavity $2.7 \AA^{50}$ ) (SI Figure S4C). Aqueous Fe(II) represented $4-13 \%$ of total 
$\mathrm{Fe}(\mathrm{II})$, and basal-sorbed $\mathrm{Fe}(\mathrm{II})$ accounted for the smallest percentage $(1-5 \%)$. Further HF treatment recovered less than $2 \%$ of total produced $\mathrm{Fe}(\mathrm{II})$, indicating that $0.5 \mathrm{M} \mathrm{HCl}$ was sufficient to recover all structural $\mathrm{Fe}$ (II) in our experiments.

Dissolved and sorbed silica concentrations indicated a maximum of $1.6 \%$ clay mineral dissolution (SI Figure S5), which is consistent with limited reductive dissolution of $\mathrm{Fe}$ containing clays. ${ }^{17}$ No Fe-bearing secondary minerals were observed (by SEM) on clay surfaces in biologically or chemically reduced NAu- 1 after more than 400 days incubation (Figure S6, see SI for a detailed discussion).

Changes in Fe Isotope Composition during Microbial and Chemical Reduction. Significant changes in the $\mathrm{Fe}$ isotope compositions of the various $\mathrm{Fe}$ (II) and $\mathrm{Fe}$ (III) pools occurred during biological and chemical reduction (Figure 2, SI Table S4), with marked deviations from the starting bulk NAu1 composition $\left(\delta^{56} \mathrm{Fe}=0.59 \%\right)$. The $\delta^{56} \mathrm{Fe}$ values for octahedral $\mathrm{Fe}$ (III) extracted by $0.5 \mathrm{M} \mathrm{HCl}$ were calculated by assuming that structural $\mathrm{Fe}(\mathrm{II})$ in $0.5 \mathrm{M} \mathrm{HCl}$ had the same
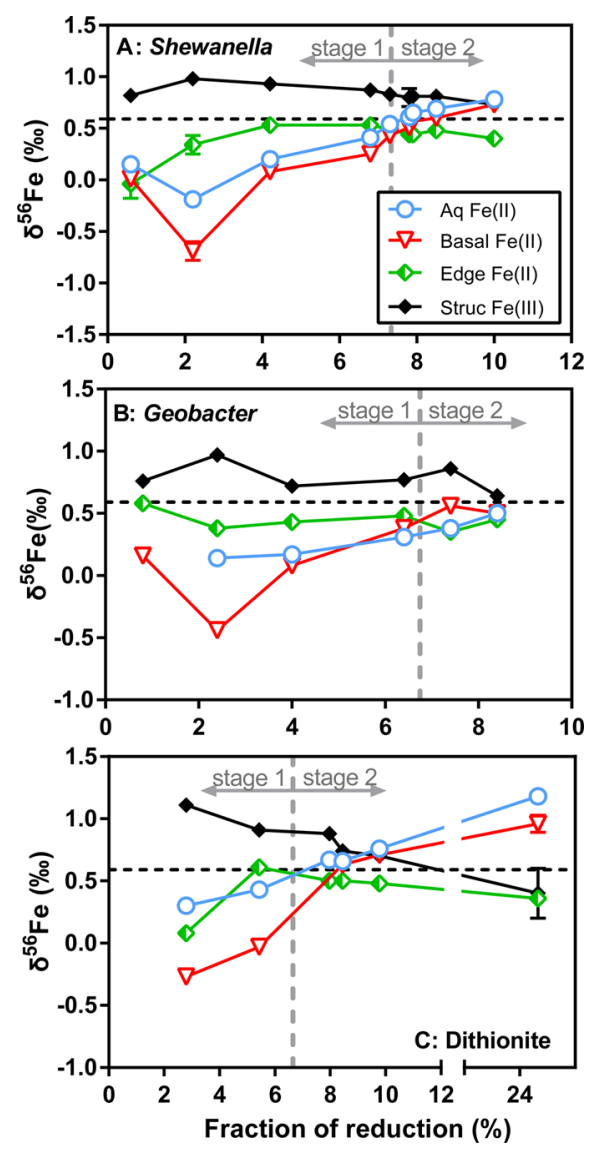

Figure 2. Iron isotope compositions of the different $\mathrm{Fe}(\mathrm{II})$ pools (aqueous, basal-sorbed, and edge plus structural sites) and structural $\mathrm{Fe}(\mathrm{III})$ in the $0.5 \mathrm{M} \mathrm{HCl}$ extracts (see SI for calculation of the latter) during NAu-1 reduction by Shewanella (A), Geobacter (B), and dithionite $(\mathrm{C})$ under $\mathrm{pH}$ 6.8. Dashed horizontal lines indicate the original $\delta^{56} \mathrm{Fe}$ value of bulk NAu-1, representing $\delta^{56} \mathrm{Fe}$ of the starting structural $\mathrm{Fe}(\mathrm{III})$. Note that, during stage 2, aqueous $\mathrm{Fe}$ (II) becomes isotopically heavier than edge plus structural $\mathrm{Fe}(\mathrm{II})$. The transition from stage 1 to stage 2 is thus characterized by systematic changes in the biological reduction kinetics (see Figure 1) and the Fe isotopic signatures. Error bars indicate one standard deviation based on either duplicate reactors for microbial reduction experiments or repeated analyses for chemical reduction experiments. isotope composition as the edge plus structural $\mathrm{Fe}(\mathrm{II})$ in the $\mathrm{NaH}_{2} \mathrm{PO}_{4}$ extract (see SI for details of calculation and mass balance discussion).

During the initial, rapid stage of reduction, structural Fe(III) extracted by $0.5 \mathrm{M} \mathrm{HCl}$ was isotopically heavier than the starting bulk NAu-1 in all reduction experiments (stage 1, Figure 2), while all the $\delta^{56} \mathrm{Fe}$ values of the different $\mathrm{Fe}(\mathrm{II})$ pools were lower than those of structural $\mathrm{Fe}$ (III). Basal-sorbed $\mathrm{Fe}(\mathrm{II})$ exhibited the most negative $\delta^{56} \mathrm{Fe}$ values among all $\mathrm{Fe}(\mathrm{II})$ pools, with the lowest values observed when the extent of reduction was slightly above $2 \%$. Edge plus structural $\mathrm{Fe}(\mathrm{II})$ generally had the heaviest $\mathrm{Fe}$ isotopic compositions of all the $\mathrm{Fe}(\mathrm{II})$ pools, while aqueous $\mathrm{Fe}(\mathrm{II})$ exhibited intermediate $\delta^{56} \mathrm{Fe}$ values between those of basal and edge plus structural $\mathrm{Fe}$ (II). The isotopic $\mathrm{Fe}$ compositions of all three $\mathrm{Fe}(\mathrm{II})$ pools converged toward that of the starting bulk NAu-1 by the end of stage 1 .

During the second stage of reduction, the $\mathrm{Fe}$ isotope composition of aqueous and basal-sorbed Fe(II) continued to become isotopically heavier, while that of edge plus structural $\mathrm{Fe}$ (II) decreased or remained constant (stage 2, Figure 2, SI Table S4). The final $\delta^{56} \mathrm{Fe}$ values of aqueous and basal-sorbed $\mathrm{Fe}(\mathrm{II})$ were close to (Geobacter reactors, Figure 2B), or even higher than (Shewanella and chemical reactors, Figure $2 \mathrm{~A}$ and $\mathrm{C})$, that of the starting bulk clay. Meanwhile, the $\delta^{56} \mathrm{Fe}$ values of edge plus structural $\mathrm{Fe}$ (II) and structural $\mathrm{Fe}$ (III) decreased with increasing extent of reduction (Figure 2) until, in the chemical reduction experiments, the two eventually reached identical $\delta^{56} \mathrm{Fe}$ values below that of the starting bulk clay (Figure 2C). Although three chemical reactors in stage 2 were run at elevated temperature $\left(70^{\circ} \mathrm{C}\right)$ and one reactor at room temperature (SI Table S1), the general trends of the Fe isotope compositions were quite similar to those observed in the microbial reduction experiments (Figure 2).

Changes in Fe Isotope Composition during Clay$\mathrm{Fe}$ (II) Exchange. In the exchange experiments, the Fe isotope compositions of the different $\mathrm{Fe}$ pools deviated from the $\delta^{56} \mathrm{Fe}$ values of starting NAu-1 and aqueous $\mathrm{Fe}(\mathrm{II})$ after 30 and 57 days (Figure 3). Structural Fe extracted by $0.5 \mathrm{M} \mathrm{HCl}$ was isotopically heavier than the starting NAu-1. Aqueous and basal-sorbed $\mathrm{Fe}$ were isotopically lighter than the $\mathrm{Fe}$ (II) added at the start of the experiments, while $\mathrm{NaH}_{2} \mathrm{PO}_{4}$ extractable $\mathrm{Fe}$ was heavier. During the entire duration of the exchange experiments, $\mathrm{pH}$ remained stable at 6 . The extent of atom

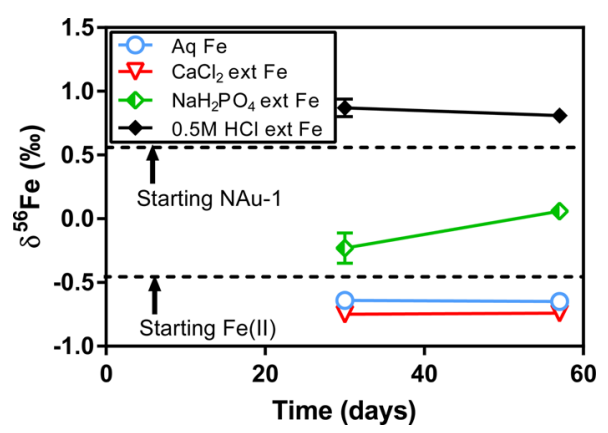

Figure 3. Iron isotope compositions of different Fe pools upon mixing of aqueous $\mathrm{Fe}$ (II) with NAu-1 (Fe molar ratio: 1:4, pH 6.0). The black horizontal lines indicate the starting $\delta^{56} \mathrm{Fe}$ values of bulk NAu-1 and aqueous $\mathrm{Fe}(\mathrm{II})$, respectively. Error bars indicate one standard deviation based on two duplicate reactors and are smaller than symbol size when not shown. 
exchange has been shown to be ca. $4 \%$ between aqueous $\mathrm{Fe}$ (II) and NAu-1 based on $\delta^{57} \mathrm{Fe}$ values, which have been reported previously. ${ }^{51}$ The $\delta^{56} \mathrm{Fe}$ data for the same experiments have been first reported in the current study.

\section{DISCUSSION}

Two-Stage Microbial and Chemical Clay Reduction. We hypothesize that, in both the microbial and chemical reduction experiments, structural $\mathrm{Fe}$ reduction proceeds in two consecutive stages (SI Figure S4A-C). During stage 1, electrons are supplied to structural $\mathrm{Fe}$ (III) atoms in the edge sites of $\mathrm{NAu}-1$. The resulting structural $\mathrm{Fe}$ (II) is released from the octahedral sheet and attaches to hydroxyl groups, producing edge-bound $\mathrm{Fe}(\mathrm{II})$. A small amount of $\mathrm{Fe}(\mathrm{II})$ is released to solution, and subsequently partially adsorbs onto basal planes (SI Figure S4A). Edge-bound and aqueous Fe(II) undergoes ETAE with structural $\mathrm{Fe}$ (III) located near to the clay particle edges. Shewanella oneidensis, which is able to release electron shuttling compounds, ${ }^{52}$ reduces $\sim 7 \%$ of total $\mathrm{Fe}(\mathrm{III})$ within 8 days (Figure 1C), while G. sulfurreducens, which does not release electron shuttling compounds and requires direct cell contact to mineral surfaces, ${ }^{52}$ only achieves $\sim 2 \%$ reduction after 126 days (Figure 1C). However, the extent of reduction by G. sulfurreducens increases rapidly to $\sim 6 \%$ within 7 days after addition of AQDS as an exogenous electron shuttle.

When assessing the electron transfer pathways in our microbial reduction experiments, two models have been proposed by previous studies: a parallel-to-layer pathway initiating from the edge sites ${ }^{18,19}$ vs both parallel-to-layer and perpendicular-to-layer through basal planes pathways. ${ }^{53}$ Bishop et al. ${ }^{53}$ used the correlation between the interlayer expandability and the extent of bioreduction to argue for possible perpendicular-to-layer electron transfer pathway during reduction by strain Shewallena putrefaciens CN32. This is inconsistent with prior Mössbauer work on bioreduced nontronite by Shewallena oneidensis MR-1, suggesting a parallel-to-layer pathway only. ${ }^{18,19}$ Both differences in bacterial strains and heterogeneity of clay particles may account for the discrepancy observed in these studies. ${ }^{53}$ It has also been shown that organic matter in the interlayer space hinders the extent and rate of bioreduction of nontronite NAu-2 by methanogens. ${ }^{54}$ However, a recent Mössbauer study of bioreduced NAu-2 reveals that perpendicular-to-layer electron transfer occurs only with the assistance of AQDS and not with Shewanella alone. ${ }^{55}$ Our limited extent of reduction argues for the dominance of the parallel-to-layer electron transfer pathway in the Shewallena experiments and the perpendicular-to-layer pathway may play a role in our Geobacter experiments with AQDS.

During stage 2, microbial reduction slows down significantly: the extent of reduction increases from $7 \%$ at day 8 to $10 \%$ at day 161 with Shewanella, and from $6 \%$ at day 162 to $8 \%$ at day 240 with Geobacter. Initial structural Fe(III) at edge sites (i.e., $\mathrm{Fe}$ (III) exposed to solution) of NAu-1 represents 2.7 to $13.6 \%$ of the total initial $\mathrm{Fe}$ (III) (considering particles ranging from 0.01 to $0.05 \mu \mathrm{m}$, see SI for details of calculation). Thus, only about $10 \%$ of the $\mathrm{Fe}$ (III) near the clay particle edges appears to be directly accessible to the iron-reducing bacteria. This pool constitutes the finite, bioavailable $\mathrm{Fe}$ (III) pool $^{5}$ (SI Figure S4B). The size of this bioavailable Fe(III) pool may differ for different clay minerals considering that clay particles are heterogeneous by nature in crystallinity, particle size, surface area, and expandability. ${ }^{53,56}$ It is worthwhile to note that the extent and rate of bioreduction is also influenced by the energetics of the system, as shown by continuing reduction after addition of fresh cells to previously ceased bioreduction experiments. ${ }^{56,57}$ In the chemical reduction experiments, dithionite, with its small molecular size, is able to diffuse into the interior of the clay structure along basal planes (SI Figure S4C), hence explaining the higher extents of reduction of total structural Fe(III) (up to 24\%, SI Table S2). It is important to note that, overall, chemical reduction by dithionite proceeds markedly faster than reduction by the two iron-reducing bacteria. The same extent of reduction achieved within minutes by dithionite requires several days in the microbial reduction experiments.

Fe Isotope Compositions. The observed changes in Fe isotope compositions are consistent with the proposed twostage mechanism for structural $\mathrm{Fe}$ (III) reduction shown diagrammatically in Figure 4 and SI Figure S4. When the extent of reduction is low (stage 1), the isotopically light aqueous $\mathrm{Fe}(\mathrm{II})$ argues for atom exchange with structural $\mathrm{Fe}$ (III) on the edge sites (Figure 4A and SI Figure S4A). In the absence of atom exchange, aqueous $\mathrm{Fe}$ (II) would be expected to inherit the $\delta^{56} \mathrm{Fe}$ signature of the outmost structural $\mathrm{Fe}$ atoms upon reductive dissolution. Partial dissolution of the starting NAu-1 shows that the outermost $\mathrm{Fe}$ atoms near the clay particle edges are isotopically heavy, while those located in the interior of the clay particles are isotopically light (see SI Table S5), which may reflect the isotope heterogeneity of the clay particles. Thus, aqueous $\mathrm{Fe}(\mathrm{II})$ would have shown a more positive $\delta^{56} \mathrm{Fe}$ value than the bulk clay (e.g., $\delta^{56} \mathrm{Fe} \geq 0.74 \%$ o when dissolution $\leq 1.5 \%$, see SI Table S5), which is not the case. The existence of atom exchange between aqueous $\mathrm{Fe}(\mathrm{II})$ and other $\mathrm{Fe}$ phases is consistent with a previous finding using enriched isotope tracers. ${ }^{51}$ Neumann et al. ${ }^{51}$ proposed that electron injection by sorbed $\mathrm{Fe}$ (II) at edge sites, followed by bulk electron conduction through the octahedral sheet, would connect oxidation of edge-bound $\mathrm{Fe}(\mathrm{II})$ with reduction of structural $\mathrm{Fe}$ (III) at spatially separated sites. Considering the much smaller pool of aqueous $\mathrm{Fe}$ (II) than edge-bound Fe(II) in our experiments, we hypothesize that ETAE between aqueous $\mathrm{Fe}(\mathrm{II})$ and structural $\mathrm{Fe}$ (III) occurs via a transient sorbed $\mathrm{Fe}$ (II) phase on edge sites, which may or may not be captured in the edge-bound $\mathrm{Fe}$ (II) extract.

For the same reason, edge plus structural $\mathrm{Fe}(\mathrm{II})$ would become isotopically heavy if only reduction (i.e., electron transfer) occurs without atom exchange. The observed isotopically light edge plus structural $\mathrm{Fe}(\mathrm{II})$ and isotopically heavy structural $\mathrm{Fe}$ (III) suggest that atom exchange is coupled with electron transfer (i.e., ETAE) during stage 1.

Basal-sorbed $\mathrm{Fe}(\mathrm{II})$ exhibits the most negative $\delta^{56} \mathrm{Fe}$ values. We propose three hypotheses to explain the observed values: 1 ) kinetic adsorption of aqueous $\mathrm{Fe}(\mathrm{II})$ onto basal planes; 2) ETAE between basal-sorbed Fe(II) and structural Fe(III); and 3) partial oxidation of basal-sorbed $\mathrm{Fe}$ (II) due to electron transfer from sorbed $\mathrm{Fe}(\mathrm{II})$ to structural $\mathrm{Fe}(\mathrm{III})$. The first hypothesis may explain the lightest basal-sorbed $\mathrm{Fe}(\mathrm{II})$ when the extent of reduction is ca. $2 \%$ (Figure 2), consistent with a kinetic sorption producing isotopically heavy aqueous $\mathrm{Fe}(\mathrm{II})$ during interaction between aqueous $\mathrm{Fe}(\mathrm{II})$ and goethite. ${ }^{58}$ However, isotope data of later time points (i.e., at day 161 in Shewallena experiments) still showed an isotopically lighter basal-sorbed $\mathrm{Fe}$ (II) than that of the aqueous Fe(II) (Figure 2), arguing against a kinetic effect to fully explain our observed data. Electron transfer from basal-sorbed $\mathrm{Fe}$ (II) to sturcutral $\mathrm{Fe}(\mathrm{III})$ has been demonstrated previously. ${ }^{36}$ However, atom 

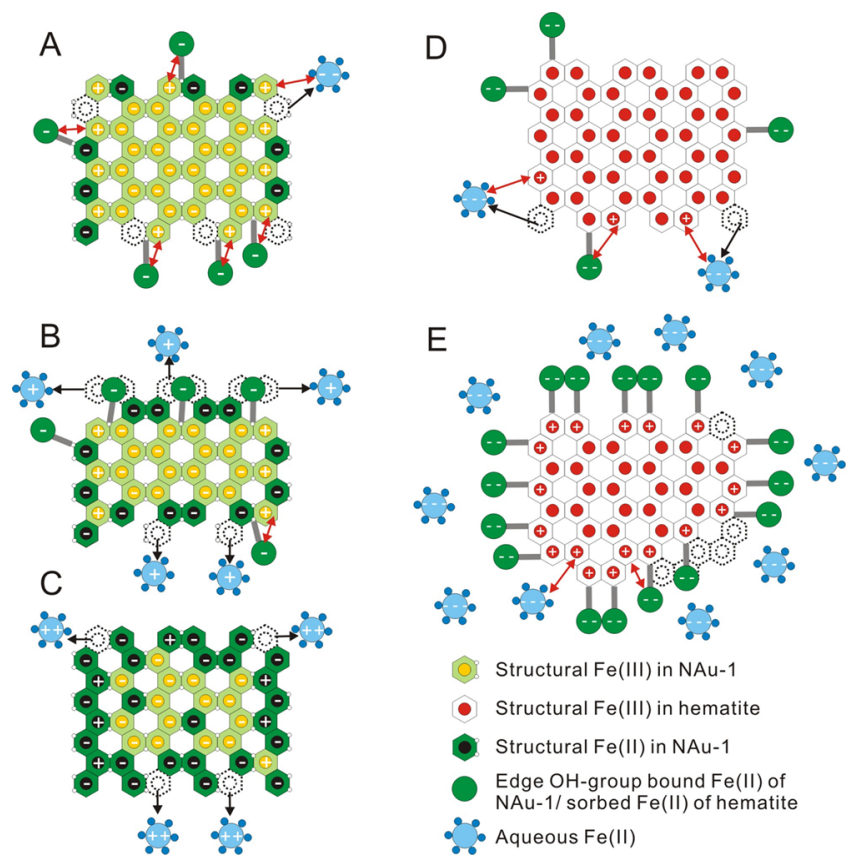

Figure 4. Comparison of reduction mechanisms of NAu-1 (top view) and hematite. (A) At low extent of reduction of NAu-1, the outmost structural $\mathrm{Fe}$ (III) is reduced by the bacteria (Shewanella and Geobacter) or dithionite to structural $\mathrm{Fe}$ (II). $\mathrm{Fe}$ (II) bound to edge hydroxyl groups and structural edge $\mathrm{Fe}$ (II) have the same isotope composition. The release of aqueous $\mathrm{Fe}$ (II) from structural $\mathrm{Fe}$ is indicated by the black arrow. ETAE between aqueous $\mathrm{Fe}$ (II) and structural $\mathrm{Fe}$ (III) and edge-bound $\mathrm{Fe}$ (II) and structural $\mathrm{Fe}$ (III) is shown by the red arrows. Basal-sorbed Fe(II) is not shown in the top view figures. (B) At high extent of reduction in biological experiments, residual heavy structural $\mathrm{Fe}(\mathrm{III})$ is reduced and dissolves, producing isotopically heavy aqueous phase $\mathrm{Fe}$ (II) (indicated by "+" and the black arrows). Edge sites are saturated with structural and edge-bound $\mathrm{Fe}(\mathrm{II})$, inhibiting further reduction. ETAE between aqueous $\mathrm{Fe}(\mathrm{II})$ and structural $\mathrm{Fe}(\mathrm{III})$ is blocked, with minor ETAE between edgebound $\mathrm{Fe}(\mathrm{II})$ and structural $\mathrm{Fe}(\mathrm{III})$, as indicated by the red arrow. (C) At $\sim 24 \%$ reduction in chemical experiments, interior structural $\mathrm{Fe}$ (III) is reduced, with a small amount of the isotopically heavy outmost $\mathrm{Fe}$ (II) released to the aqueous phase (indicated by "++"). (D) For $\mathrm{Fe}$ oxyhydroxide minerals, reduction does not cause the accumulation of structural $\mathrm{Fe}$ (II). Both aqueous (“---” indicates lowest $\delta^{56} \mathrm{Fe}$ ) and adsorbed $\mathrm{Fe}(\mathrm{II})$ (“--” indicates lower $\delta^{56} \mathrm{Fe}$ ) undergo ETAE with structural $\mathrm{Fe}$ (III) on the mineral surfaces ("+" indicates high $\delta^{56} \mathrm{Fe}$ ). (E) When surface is saturated by sorbed $\mathrm{Fe}(\mathrm{II})$, no blockage of ETAE occurs due to lack of structural $\mathrm{Fe}(\mathrm{II})$, thus maintaining isotopic equilibrium.

exchange has never been shown to occur between basal-sorbed $\mathrm{Fe}(\mathrm{II})$ and structural $\mathrm{Fe}(\mathrm{III})$, presumably due to physical blockage by a tetrahedral sheet between the two. Thus, we reject the second hypothesis. Meanwhile, if basal-sorbed Fe(II) was partially oxidized to $\mathrm{Fe}(\mathrm{III})$, then residual $\mathrm{Fe}(\mathrm{II})$ will be isotopically lighter than the original sorbed $\mathrm{Fe}(\mathrm{II}),{ }^{59,60}$ which presumably had a similar isotope composition with the aqueous $\mathrm{Fe}(\mathrm{II})$. Due to the small quantity of this $\mathrm{Fe}(\mathrm{III})$ product, our $\mathrm{CaCl}_{2}$ extraction and/or the Ferrozine method may fail to recover this $\mathrm{Fe}(\mathrm{III})$ phase. This third one remains a viable hypothesis to be tested further.

During stage 2, the progressively heavier isotopic compositions of aqueous and basal-sorbed $\mathrm{Fe}$ (II) (Figure 2) are explained by the continued reductive dissolution of the outermost pool of structural $\mathrm{Fe}(\mathrm{III})$ and the cessation of
ETAE between aqueous $\mathrm{Fe}$ (II) and structural Fe(III). During this stage, some ETAE between edge-bound $\mathrm{Fe}(\mathrm{II})$ and adjacent structural $\mathrm{Fe}$ (III) is still possible, due to close site contact, but not between aqueous $\mathrm{Fe}(\mathrm{II})$ and structural $\mathrm{Fe}$ (III) (Figure 4B and SI Figure S4B). In other words, the accumulation of structural $\mathrm{Fe}$ (II) along the edges of the clay particles causes the blocking of ETAE.

Compared to the near-edge, bioavailable Fe(III) pool, the interior $\mathrm{Fe}$ (III) pool is not accessible to the bacteria. The small dithionite molecules, however, are able to further reduce a significant portion of the interior $\mathrm{Fe}(\mathrm{III})$ pool (Figure $4 \mathrm{C}$ and SI Figure S4C). The aqueous and basal-sorbed Fe(II) thus derives from the reductive dissolution of a relatively small portion of the outermost component of the $\mathrm{Fe}(\mathrm{III})$ pool with $\delta^{56} \mathrm{Fe}$ values of $\sim 1 \%$ (SI Table S4). Structural $\mathrm{Fe}(\mathrm{II})$ and structural $\mathrm{Fe}(\mathrm{III})$ are both isotopically light (Figures $2 \mathrm{C}$ and $4 \mathrm{C})$, reflecting the inheritance of the light $\delta^{56} \mathrm{Fe}$ values of the bulk interior Fe(III) pool, without ETAE (see SI Table S5). Alternatively, the aqueous plus basal-sorbed $\mathrm{Fe}(\mathrm{II})$ could become enriched in heavy $\mathrm{Fe}$ isotopes due to the precipitation of an isotopically light secondary mineral phase during stage 2 . However, no secondary mineral precipitates could be detected by SEM in all the reduced samples, even at the highest extents of $\mathrm{Fe}(\mathrm{III})$ reduction (SI Figure S6).

Fe Isotope Fractionations. With the exception of the initial data points, the $\mathrm{Fe}$ isotope fractionation factors in the microbial and chemical reduction experiments generally decrease with increasing extent of reduction during stage 1 (Figure 5 and SI Figure S7, Table S4). The fractionation factors between edge plus structural $\mathrm{Fe}(\mathrm{II})$ and structural $\mathrm{Fe}(\mathrm{III})$ on the one hand (Figure 5A), and the combined $\mathrm{Fe}$ (II) pools and structural $\mathrm{Fe}$ (III) on the other (SI Figure S7), both decrease from -1.0 to $-0.3 \%$; their near identical trends reflect the dominant contribution of edge plus near-edge structural Fe(II)

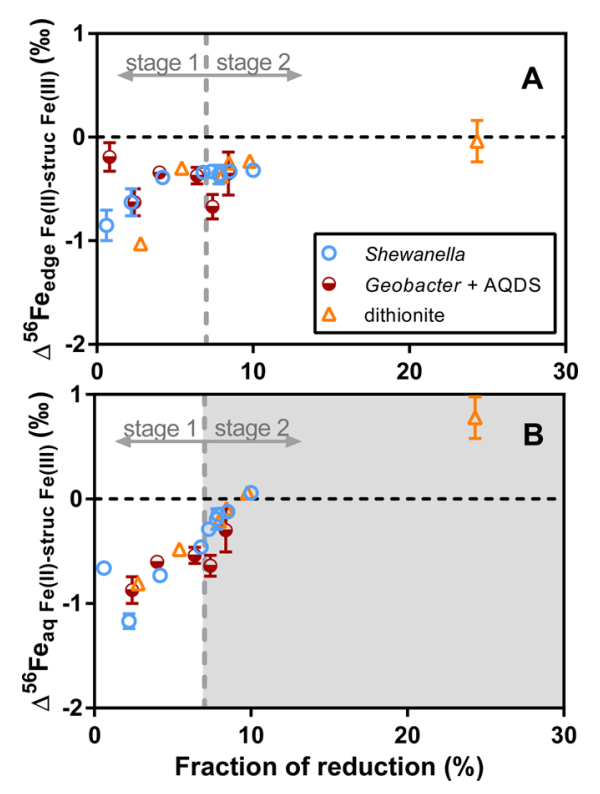

Figure 5. Changes in the $\mathrm{Fe}$ isotope fractionation factors $\Delta^{56} \mathrm{Fe}_{\text {edge }} \mathrm{Fe}(\mathrm{II})$-struc $\mathrm{Fe}(\mathrm{III})$ (panel A) and $\Delta^{56} \mathrm{Fe} \mathrm{e}_{\mathrm{aq}} \mathrm{Fe}$ (II)-struc $\mathrm{Fe}(\mathrm{III})$ (panel $\mathrm{B})$ in biological and chemical reduction experiments plotted against the extent of reduction. The vertical lines indicate the transition from stage 1 to stage 2 . The gray background in stage 2 of panel B shows that no ETAE occurs between aqueous $\mathrm{Fe}(\mathrm{II})$ and structural $\mathrm{Fe}(\mathrm{III})$. Error bars indicate one standard deviation of propagated errors. 
to total $\mathrm{Fe}(\mathrm{II})$. The decreasing trends are explained by the finite size of the bioavailable $\mathrm{Fe}$ (III) pool. At the onset of reduction, the fractionation factors are the largest due to extensive ETAE. With reduction proceeding, edge sites are progressively occupied by $\mathrm{Fe}(\mathrm{II})$, resulting in less structural $\mathrm{Fe}$ (III) available for ETAE, and the fractionation factors decrease. In all the reduction experiments, the maximum fractionation factors are observed for $\Delta^{56} \mathrm{Fe}_{\mathrm{aq}} \mathrm{Fe}(\mathrm{II})$-struc $\mathrm{Fe}(\mathrm{III})(-1.2$ to $-0.8 \%$ o $)$ when the extent of reduction is small, ca. $2 \%$ (Figure $5 \mathrm{~B}$ ). These large values reflect extensive ETAE between aqueous $\mathrm{Fe}$ (II) and structural $\mathrm{Fe}$ (III) assisted by dynamic sorption/desorption via a transient sorbed $\mathrm{Fe}$ (II) phase (Figure 4A and SI Figure S4A).

During stage 2, as the finite bioavailable Fe(III) pool is nearly exhausted, the reduction rates in the Shewanella reactors drop to very low values, while the $\Delta^{56} \mathrm{Fe}_{\text {struc }} \mathrm{Fe}$ (II)-struc $\mathrm{Fe}$ (III) values stabilize at $-0.34 \pm 0.02 \%$ (Figure $5 \mathrm{~A}$ ), reflecting minor ETAE between edge-bound $\mathrm{Fe}(\mathrm{II})$ and structural $\mathrm{Fe}(\mathrm{III})$ (Figure 4B andSI Figure S4B). In the experiments with dithionite, much faster reduction ultimately results in $\Delta \Delta^{56} \mathrm{Fe}_{\text {struc } \mathrm{Fe}(\mathrm{II}) \text {-struc } \mathrm{Fe}(\mathrm{III})}$ values of $\sim 0 \%$ (Figure $5 \mathrm{~A}$ ), while the extent of reduction reaches $24 \%$. The net zero isotopic fractionation implies that $100 \%$ of the structural $\mathrm{Fe}(\mathrm{III})$ pool accessible to dithionite has been reduced at that point.

In the microbial reduction experiments, fractionation factors between aqueous $\mathrm{Fe}(\mathrm{II})$ and structural $\mathrm{Fe}(\mathrm{III})$ change from $-0.3 \%$ o to $0.1 \%$ o during stage 2 (Figure $5 \mathrm{~B}$ ), which signals the progressive cessation of ETAE and the cumulative release of isotopically heavy $\mathrm{Fe}$ to solution (Figure $4 \mathrm{~B}$ and SI Figure S4B). When the two phases coincidentally attain the same isotopic composition, the bioavailable $\mathrm{Fe}$ (III) pool is completely consumed. At the end of the chemical reduction experiments, that is, at $24 \%$ reduction, the $\Delta^{56} \mathrm{Fe}_{\mathrm{aq} \mathrm{Fe}(\mathrm{II}) \text {-struc } \mathrm{Fe}(\mathrm{III})}$ value has become positive due to the absence of atom exchange between aqueous $\mathrm{Fe}$ (II) and structural $\mathrm{Fe}$ (III) and between aqueous $\mathrm{Fe}$ (II) and structural $\mathrm{Fe}(\mathrm{II})$. At this stage, all the edge sites are saturated with $\mathrm{Fe}$ (II) and a lack of atom exchange between aqueous $\mathrm{Fe}$ (II) and structural $\mathrm{Fe}$ (II) indicates that atom exchange must be coupled with electron transfer. Facilitation of atom exchange by electron transfer has been shown previously by the higher extent of atom exchange for interactions between aqueous $\mathrm{Fe}(\mathrm{II})$ and $\mathrm{Fe}$ oxyhydroxides than between aqueous $\mathrm{Fe}$ (III) and amorphous Fe oxide. ${ }^{28}$ This in turn demonstrates that ETAE is the key mechanism for $\mathrm{Fe}$ isotope fractionation during the first stage of clay reduction (Figure 4A and SI Figure S4A).

Comparison to $\mathrm{Fe}(\mathrm{II})-\mathrm{NAu}-1$ Exchange Experiments. Similar to the stage 1 results of the microbial and chemical reduction experiments, the mixing of aqueous $\mathrm{Fe}(\mathrm{II})$ and NAu1 produces structural $\mathrm{Fe}(\mathrm{III})$ that is isotopically heavier than the starting clay material, as well as isotopically light $\mathrm{Fe}$ (II) (Figure 3). However, the relatively constant isotopic compositions and fractionation factors during the exchange experiments contrast with the time-dependent trends seen in the reduction experiments. A previous study has shown that mixing aqueous $\mathrm{Fe}(\mathrm{II})$ and $\mathrm{NAu}-1$ at $\mathrm{pH} \quad 6$ causes $\sim 3 \%$ reduction of structural $\mathrm{Fe}(\mathrm{III}){ }^{33}$ The isotope fractionation factors in the mixing experiments are in general comparable to those of the reduction experiments at $\sim 3 \%$ extent of reduction (SI Table S4). Due to the small extent of reduction, only limited structural $\mathrm{Fe}$ (II) is generated and no saturation of edge sites over time would occur in the mixing experiments. The invariant isotope fractionation factors with time imply a constant extent of ETAE throughout the mixing experiments.
The small differences between the fractionation factors observed in the exchange and reduction experiments (SI Table S4) could be due to differences in the amounts of $\mathrm{Fe}$ (II) sorbed onto basal and edge sites because of $\mathrm{pH}$ differences $(6.0$ in exchange experiments versus 6.8 in reduction experiments). ${ }^{36}$

Iron Reduction in Clay Mineral Versus Fe(III) Oxyhydroxides. The in situ reduction of structural $\mathrm{Fe}$ (III) which leads to the blocking of ETAE between aqueous $\mathrm{Fe}$ (II) and structural $\mathrm{Fe}$ (III) is unique to clay minerals with layered structure, and distinct from $\mathrm{Fe}$ (III) oxyhydroxide mineral reduction. Before the bioavailable finite $\mathrm{Fe}(\mathrm{III})$ pool is exhausted, ETAE mainly takes place between edge-bound $\mathrm{Fe}(\mathrm{II})$ and structural $\mathrm{Fe}(\mathrm{III})$, as well as between aqueous $\mathrm{Fe}(\mathrm{II})$ and structural $\mathrm{Fe}(\mathrm{III})$ (Figure 4A). With the accumulation of structural $\mathrm{Fe}$ (II), the amount of structural $\mathrm{Fe}(\mathrm{III})$ available for ETAE with aqueous $\mathrm{Fe}$ (II) decreases. Ultimately, ETAE with the interior structural $\mathrm{Fe}$ (III) pool ceases (Figure $4 \mathrm{~B}$ and SI Figure S4B). Basal-sorbed Fe(II) does not undergo ETAE with structural $\mathrm{Fe}$ (III) due to the physical separation by the tetrahedral sheets (SI Figure S4A). In contrast, Fe(II) produced during the reduction of $\mathrm{Fe}$ (III) oxyhydroxides mainly ends up in the aqueous and adsorbed phases (Figure 4D). Even when the surface of the $\mathrm{Fe}(\mathrm{III})$ oxyhydroxide mineral is saturated with adsorbed $\mathrm{Fe}(\mathrm{II})$, structural $\mathrm{Fe}$ (III) remains available to ETAE with aqueous and adsorbed $\mathrm{Fe}$ (II), due to the lack of blockage by structural $\mathrm{Fe}$ (II) (Figure 4E). Thus, aqueous $\mathrm{Fe}(\mathrm{II})$ can maintain isotopic equilibrium with solid-phase $\mathrm{Fe}(\mathrm{III})$ and remain isotopically lighter than sorbed Fe(II). . $^{27,30,31}$

Our results imply that $\mathrm{Fe}$ isotope fractionations can potentially yield signatures that may allow one to distinguish reduction of structural $\mathrm{Fe}$ (III) in layered clay minerals by dissimilatory iron reducing bacteria from reduction of $\mathrm{Fe}(\mathrm{III})$ oxyhydroxides in reducing environments. When most bioavailable $\mathrm{Fe}$ (III) in clays is exhausted, microbial reduction becomes inhibited due to site saturation, and further ETAE between aqueous $\mathrm{Fe}$ (II) and structural $\mathrm{Fe}$ (III) no longer takes place. The complete conversion of bioavailable $\mathrm{Fe}$ (III) to $\mathrm{Fe}(\mathrm{II})$ in clay (zero fractionation between aqueous phase and structural $\mathrm{Fe}(\mathrm{III})$ in mineral), coupled with limited reductive dissolution $(\sim 1 \%)$, indicates that Fe redox cycling mediated by microbes may be an isotopically reversible process. This conclusion is consistent with recent bulk measurements of clay redox speciation which indicate that ferruginous clay may serve as a rechargeable energy source for bacteria in soils and sediments. ${ }^{55}$ The blockage of ETAE will likely also influence the reactivity of edge plus structural $\mathrm{Fe}$ (II) toward nutrients and contaminants, which warrants further exploration.

The $\mathrm{Fe}$ isotope compositions of major Fe-bearing minerals (i.e., magnetite, siderite) in the Banded Iron Formations in the rock record have been interpreted as biosignatures of dissimilatory iron reduction (DIR) of $\mathrm{Fe}$ (III) oxyhydroxides either in situ ${ }^{61-63}$ in the sediments or through a benthic shuttle. ${ }^{64,65}$ This interpretation is largely based on the generation of isotopically light $\mathrm{Fe}$ (II) by $\mathrm{DIR}$ of $\mathrm{Fe}(\mathrm{III})$ oxyhdroxides as demonstrated in numerous experimental studies. $^{29-31}$ Our findings here imply that $\mathrm{Fe}$ bearing clay minerals may not serve as a faithful recorder of microbial activities (i.e., DIR) on ancient Earth. If bioavailable $\mathrm{Fe}$ was exhausted during microbial reduction, no distinctive $\mathrm{Fe}$ isotope signature would be detected for the end product ferrous phases when analyzing clay minerals in the rock record. On the other 
hand, a lack of isotope discrepancy between ferrous and ferric phases associated with clay minerals cannot be used to rule out the existence of microbial activities.

\section{ASSOCIATED CONTENT}

\section{S Supporting Information}

The Supporting Information is available free of charge on the ACS Publications website at DOI: 10.1021/acs.est.6b02019.

Additiional information as noted in the text (PDF)

\section{AUTHOR INFORMATION}

\section{Corresponding Author}

*Phone: 1-519-888-4567 ext. 33235; fax: 1-519-746-7484; email: lingling.wu@uwaterloo.ca.

Notes

The authors declare no competing financial interest.

\section{ACKNOWLEDGMENTS}

We are deeply indebted for data on exchange experiments and insightful comments provided by Anke Neumann and Michelle Scherer (University of Iowa). Funding for this work was provided by an Ontario Early Researcher Award and NSERC Discovery grant awarded to LW, the NASA Astrobiology Institute, and the Canada Excellence Research Chair (CERC) program.

\section{REFERENCES}

(1) Stucki, J. W.; Faïza Bergaya, B. K. G. T. a. G. L., Chapter 8 Properties and Behaviour of Iron in Clay Minerals. In Developments in Clay Science; Elsevier, 2006; Vol. 1, pp 423-475.

(2) Hofstetter, T. B.; Neumann, A.; Schwarzenbach, R. P. Reduction of nitroaromatic compounds by $\mathrm{Fe}$ (II) species associated with ironrich smectites. Environ. Sci. Technol. 2006, 40 (1), 235-242.

(3) Peretyazhko, T. S.; Zachara, J. M.; Kukkadapu, R. K.; Heald, S. M.; Kutnyakov, I. V.; Resch, C. T.; Arey, B. W.; Wang, C. M.; Kovarik, L.; Phillips, J. L.; Moore, D. A. Pertechnetate $\left(\mathrm{TcO}_{4}{ }^{-}\right)$reduction by reactive ferrous iron forms in naturally anoxic, redox transition zone sediments from the Hanford Site, USA. Geochim. Cosmochim. Acta 2012, 92 (0), 48-66.

(4) Wu, L. M.; Zhou, C. H.; Keeling, J.; Tong, D. S.; Yu, W. H. Towards an understanding of the role of clay minerals in crude oil formation, migration and accumulation. Earth-Sci. Rev. 2012, 115 (4), 373-386.

(5) Jaisi, D. P.; Kukkadapu, R. K.; Eberl, D. D.; Dong, H. Control of $\mathrm{Fe}$ (III) site occupancy on the rate and extent of microbial reduction of $\mathrm{Fe}(\mathrm{III})$ in nontronite. Geochim. Cosmochim. Acta 2005, 69 (23), 54295440.

(6) Stucki, J. W., Properties and behaviour of iron in clay minerals. In Handbook of Clay Science; Bergaya, F.; Theng, B. K. G.; Lagaly, G., Eds.; Elsevier: Boston, 2006.

(7) Stucki, J. W. A review of the effects of iron redox cycles on smectite properties. C. R. Geosci. 2011, 343 (2-3), 199-209.

(8) Stucki, J. W.; Lee, K.; Zhang, L.; Larson, R. A. Effects of iron oxidation state on the surface and structural properties of smectites. Pure Appl. Chem. 2002, 74 (11), 2145-2158.

(9) Stucki, J. W.; Tessier, D. Effects of iron oxidation state on the texture and structural order of Na-nontronite Gels. Clays Clay Miner. 1991, 39 (2), 137-143.

(10) Abollino, O.; Aceto, M.; Malandrino, M.; Sarzanini, C.; Mentasti, E. Adsorption of heavy metals on Na-montmorillonite. Effect of $\mathrm{pH}$ and organic substances. Water Res. 2003, 37 (7), 16191627.

(11) Catalano, J. G.; Brown, G. E. Uranyl adsorption onto montmorillonite: Evaluation of binding sites and carbonate complexation. Geochim. Cosmochim. Acta 2005, 69 (12), 2995-3005.
(12) Haderlein, S. B.; Weissmahr, K. W.; Schwarzenbach, R. P. Specific adsorption of nitroaromatic: explosives and pesticides to clay minerals. Environ. Sci. Technol. 1996, 30 (2), 612-622.

(13) Kostka, J. E.; Haefele, E.; Viehweger, R.; Stucki, J. W. Respiration and dissolution of iron(III)- containing clay minerals by bacteria. Environ. Sci. Technol. 1999, 33, 3127-3133.

(14) Kostka, J. E.; Wu, J.; Nealson, K. H.; Stucki, J. W. The impact of structural $\mathrm{Fe}(\mathrm{III})$ reduction by bacteria on the surface chemistry of smectite clay minerals. Geochim. Cosmochim. Acta 1999, 63 (22), 3705-3713.

(15) Dong, H.; Kostka, J. E.; Kim, J. Microscopic Evidence for Microbial Dissolution of Smectite. Clays Clay Miner. 2003, 51 (5), $502-512$.

(16) Stucki, J. W.; Lee, K.; Zhang, L.; Larson, R. A. Effects of iron oxidation state on the surface and structural properties of smectites. Pure Appl. Chem. 2002, 74 (11), 2145-2158.

(17) Dong, H. L.; Jaisi, D. P.; Kim, J.; Zhang, G. X. Microbe-clay mineral interactions. Am. Mineral. 2009, 94 (11-12), 1505-1519.

(18) Ribeiro, F. R.; Fabris, J. D.; Kostka, J. E.; Komadel, P.; Stucki, J. W. Comparisons of structural iron reduction in smectites by bacteria and dithionite: II. A variable-temperature Mossbauer spectroscopic study of Garfield nontronite. Pure Appl. Chem. 2009, 81 (8), 14991509.

(19) Komadel, P.; Madejova, J.; Stucki, J. W. Structural Fe(III) reduction in smectites. Appl. Clay Sci. 2006, 34 (1-4), 88-94.

(20) Lee, K.; Kostka, J. E.; Stucki, J. W. Comparisons of structural Fe reduction in smectites by bacteria and dithionite: An infrared spectroscopic study. Clays Clay Miner. 2006, 54 (2), 195-208.

(21) Kashefi, K.; Shelobolina, E. S.; Elliott, W. C.; Lovley, D. R. Growth of Thermophilic and Hyperthermophilic Fe(III)-Reducing Microorganisms on a Ferruginous Smectite as the Sole Electron Acceptor. Appl. Environ. Microbiol. 2008, 74 (1), 251-258.

(22) Kostka, J. E.; Haefele, E.; Viehweger, R.; Stucki, J. W. Respiration and dissolution of iron(III)-containing clay minerals by bacteria. Environ. Sci. Technol. 1999, 33 (18), 3127-3133.

(23) Kim, J.; Dong, H. L.; Seabaugh, J.; Newell, S. W.; Eberl, D. D. Role of microbes in the smectite-to-Illite reaction. Science 2004, 303, 830-832.

(24) Johnson, C. M.; Beard, B. L.; Roden, E. E. The iron isotope fingerprints of redox and biogeochemical cycling in modern and ancient Earth. Annu. Rev. Earth Planet. Sci. 2008, 36, 457-493.

(25) Hofmann, A.; Bekker, A.; Rouxel, O.; Rumble, D.; Master, S. Multiple sulphur and iron isotope composition of detrital pyrite in Archaean sedimentary rocks: A new tool for provenance analysis. Earth Planet. Sci. Lett. 2009, 286 (3-4), 436-445.

(26) Nishizawa, M.; Yamamoto, H.; Ueno, Y.; Tsuruoka, S.; Shibuya, T.; Sawaki, Y.; Yamamoto, S.; Kon, Y.; Kitajima, K.; Komiya, T.; Maruyama, S.; Hirata, T. Grain-scale iron isotopic distribution of pyrite from Precambrian shallow marine carbonate revealed by a femtosecond laser ablation multicollector ICP-MS technique: Possible proxy for the redox state of ancient seawater. Geochim. Cosmochim. Acta 2010, 74 (9), 2760-2778.

(27) Crosby, H. A.; Johnson, C. M.; Roden, E. E.; Beard, B. L. Coupled $\mathrm{Fe}(\mathrm{II})-\mathrm{Fe}(\mathrm{III})$ electron and atom exchange as a mechanism for $\mathrm{Fe}$ isotope fractionation during dissimilatory iron oxide reduction. Environ. Sci. Technol. 2005, 39, 6698-6704.

(28) Wu, L.; Percak-Dennett, E. M.; Beard, B. L.; Roden, E. E.; Johnson, C. M. Stable iron isotope fractionation between aqueous $\mathrm{Fe}(\mathrm{II})$ and model Archean ocean Fe-Si coprecipitates and implications for iron isotope variations in the ancient rock record. Geochim. Cosmochim. Acta 2012, 84 (0), 14-28.

(29) Crosby, H. A.; Roden, E. E.; Johnson, C. M.; Beard, B. L. The mechanisms of iron isotope fractionation produced during dissimilatory $\mathrm{Fe}(\mathrm{III})$ reduction by Shewanella putrefaciens and Geobacter sulfurreducens. Geobiology 2007, 5, 169-189.

(30) Percak-Dennett, E. M.; Roden, E. E.; Beard, B. L.; Johnson, C. $M$. Iron isotope fractionation during dissimilatory iron reduction under simulated Archean conditions. Geobiology 2011, 9 (3), 205220. 
(31) Wu, L.; Beard, B. L.; Roden, E. E.; Johnson, C. M. Influence of $\mathrm{pH}$ and dissolved $\mathrm{Si}$ on $\mathrm{Fe}$ isotope fractionation during dissimilatory microbial reduction of hematite. Geochim. Cosmochim. Acta 2009, 73 (19), 5584-5599.

(32) Beard, B. L.; Handler, R. M.; Scherer, M. M.; Wu, L.; Czaja, A. D.; Heimann, A.; Johnson, C. M. Iron isotope fractionation between aqueous ferrous iron and goethite. Earth Planet. Sci. Lett. 2010, 295 (1-2), 241-250.

(33) Skulan, J. L.; Beard, B. L.; Johnson, C. M. Kinetic and equilibrium $\mathrm{Fe}$ isotope fractionation between aqueous $\mathrm{Fe}(\mathrm{III})$ and hematite. Geochim. Cosmochim. Acta 2002, 66 (17), 2995-3015.

(34) Wu, L.; Beard, B. L.; Roden, E. E.; Johnson, C. M. Stable iron isotope fractionation between aqueous $\mathrm{Fe}(\mathrm{II})$ and hydrous ferric oxide. Environ. Sci. Technol. 2011, 45 (5), 1847-1852.

(35) Keeling, J. L.; Raven, M. D.; Gates, W. P. Geology and characterization of two hydrothermal nontronites from weathered metamorphic rocks at the Uley graphite mine, South Australia. Clays Clay Miner. 2000, 48 (5), 537-548.

(36) Neumann, A.; Olson, T. L.; Scherer, M. M. Spectroscopic evidence for $\mathrm{Fe}(\mathrm{II})-\mathrm{Fe}(\mathrm{III})$ electron transfer at clay mineral edge and basal sites. Environ. Sci. Technol. 2013, 47 (13), 6969-6977.

(37) Jackson, M. L. Soil Chemical Analysis: Advanced Course; Madison, WI, 1956.

(38) Myers, C. R.; Nealson, K. H. Bacterial manganese reduction and growth with manganese oxide as the sole electron acceptor. Science 1988, 240, 1319-1321.

(39) Caccavo, F.; Lonergan, D. J.; Lovley, D. R.; Davis, M.; Stolz, J. F.; McInerney, M. J. Geobacter sulfurreducens sp. nov., a hydrogenand acetate-oxidizing dissimilatory metal-reducing microorganism. Appl. Environ. Microbiol. 1994, 60, 3752-3759.

(40) Luan, F.; Gorski, C. A.; Burgos, W. D. Thermodynamic controls on the microbial reduction of iron-bearing nontronite and uranium. Environ. Sci. Technol. 2014, 48 (5), 2750-2758.

(41) Bergaya, F.; Lagaly, G.; Vayer, M., Chapter 12.10 Cation and Anion Exchange. In Developments in Clay Science; Bergaya, F.; Theng, B. K. G.; Lagaly, G., Eds. Elsevier, 2006; Vol. 1, pp 979-1001.

(42) Schoonheydt, R. A.; Johnston, C. T., Chapter 3 Surface and Interface Chemistry of Clay Minerals. In Developments in Clay Science; Bergaya, F.; Theng, B. K. G.; Lagaly, G., Eds.; Elsevier, 2006; Vol. 1, pp $87-113$.

(43) Amonette, J. E.; Templeton, J. C. Improvements to the quantitative assay of nonrefractory minerals for $\mathrm{Fe}$ (II) and total $\mathrm{Fe}$ using 1, 10-phenanthroline. Clays Clay Miner. 1998, 46 (1), 51-62.

(44) Stookey, L. L. Ferrozine- A New Spectrophotometric Reagent for Iron. Anal. Chem. 1970, 42 (7), 779-781.

(45) Schilt, A. A. Analytical Application of 1, 10- Phenanthroline and Related Compounds. Pergamon Press: Oxford; New York, 1969; Vol. 32.

(46) Clesceri, L. S.; Greenberg, A. E.; Eaton, A. D. Standard Methods for the Examination of Water and Wastewater. American Public Health Association: Washington, D. C., 1989.

(47) Beard, B. L.; Johnson, C. M.; Skulan, J. L.; Nealson, K. H.; Cox, L.; Sun, H. Application of $\mathrm{Fe}$ isotopes to tracing the geochemical and biological cycling of Fe. Chem. Geol. 2003, 195 (1-4), 87-117.

(48) Kloprogge, J. T.; Komarneni, S.; Amonette, J. E. Synthesis of smectite clay minerals: a critical review. Clays Clay Miner. 1999, 47 (5), $529-554$.

(49) Weinrach, J.; Meyer, D.; Guy, J., Jr.; Michalski, P.; Carter, K.; Grubisha, D.; Bennett, D. A structural study of sodium dithionite and its ephemeral dihydrate: A new conformation for the dithionite ion. $J$. Crystallogr. Spectrosc. Res. 1992, 22 (3), 291-301.

(50) Meunier, A. Clays. Springer: 2005; p 467.

(51) Neumann, A.; Wu, L.; Li, W.; Beard, B. L.; Johnson, C. M.; Rosso, K. M.; Frierdich, A. J.; Scherer, M. M. Atom Exchange between Aqueous $\mathrm{Fe}(\mathrm{II})$ and Structural $\mathrm{Fe}$ in Clay Minerals. Environ. Sci. Technol. 2015, 49 (5), 2786-2795.

(52) Nevin, K. P.; Lovley, D. R. Mechanisms for Fe(III) oxide reduction in sedimentary environments. Geomicrobiol. J. 2002, 19, 141-159.
(53) Bishop, M. E.; Dong, H.; Kukkadapu, R. K.; Liu, C.; Edelmann, $\mathrm{R}$. E. Bioreduction of Fe-bearing clay minerals and their reactivity toward pertechnetate (Tc-99). Geochim. Cosmochim. Acta 2011, 75 (18), 5229-5246.

(54) Zhang, J.; Dong, H.; Zeng, Q.; Agrawal, A. The role of Fe(III) bioreduction by methanogens in the preservation of organic matter in smectite. Chem. Geol. 2014, 389 (0), 16-28.

(55) Zhao, L.; Dong, H.; Kukkadapu, R. K.; Zeng, Q.; Edelmann, R. E.; Pentrák, M.; Agrawal, A. Biological Redox Cycling of Iron in Nontronite and Its Potential Application in Nitrate Removal. Environ. Sci. Technol. 2015, 49 (9), 5493-5501.

(56) Jaisi, D. P.; Dong, H.; Liu, C. Influence of biogenic Fe(II) on the extent of microbial reduction of $\mathrm{Fe}(\mathrm{III})$ in clay minerals nontronite, Illite, and chlorite. Geochim. Cosmochim. Acta 2007, 71 (5), 11451158.

(57) Jaisi, D. P.; Dong, H.; Plymale, A. E.; Fredrickson, J. K.; Zachara, J. M.; Heald, S.; Liu, C. Reduction and long-term immobilization of technetium by $\mathrm{Fe}(\mathrm{II})$ associated with clay mineral nontronite. Chem. Geol. 2009, 264 (1-4), 127-138.

(58) Reddy, T. R.; Frierdich, A. J.; Beard, B. L.; Johnson, C. M. The effect of $\mathrm{pH}$ on stable iron isotope exchange and fractionation between aqueous $\mathrm{Fe}(\mathrm{II})$ and goethite. Chem. Geol. 2015, 397, 118-127.

(59) Beard, B. L.; Johnson, C. M. Fe isotope variations in the modern and ancient earth and other planetary bodies. Rev. Mineral. Geochem. 2004, 55 (1), 319-357.

(60) Wu, L.; Brucker, R. P.; Beard, B. L.; Roden, E. E.; Johnson, C. M. Iron isotope characteristics of hot springs at Chocolate Pots, Yellowstone National Park. Astrobiology 2013, 13 (11), 1091-1101.

(61) Craddock, P. R.; Dauphas, N. Iron and carbon isotope evidence for microbial iron respiration throughout the Archean. Earth Planet. Sci. Lett. 2011, 303 (1-2), 121-132.

(62) Heimann, A.; Johnson, C. M.; Beard, B. L.; Valley, J. W.; Roden, E. E.; Spicuzza, M. J.; Beukes, N. J. Fe, C, and O isotope compositions of banded iron formation carbonates demonstrate a major role for dissimilatory iron reduction in $\sim 2.5$ Ga marine environments. Earth Planet. Sci. Lett. 2010, 294 (1-2), 8-18.

(63) Johnson, C. M.; Beard, B. L.; Klein, C.; Beukes, N. J.; Roden, E. E. Iron isotopes constrain biologic and abiologic processes in banded iron formation genesis. Geochim. Cosmochim. Acta 2008, 72 (1), 151169.

(64) Czaja, A. D.; Johnson, C. M.; Beard, B. L.; Eigenbrode, J. L.; Freeman, K. H.; Yamaguchi, K. E. Iron and carbon isotope evidence for ecosystem and environmental diversity in the $\sim 2.7$ to $2.5 \mathrm{Ga}$ Hamersley Province, Western Australia. Earth Planet. Sci. Lett. 2010, $292(1-2), 170-180$.

(65) Severmann, S.; Lyons, T. w.; Anbar, A.; McManus, J.; Gordon, G. Modern iron isotope perspective on the benthic iron shuttle and the redox evolution of ancient oceans. Geology 2008, 36 (6), 487-490. 